\title{
Analysis of pre-service science teachers' level of associating their chemistry knowledge with daily life and the relationship between these levels and their attitudes towards teaching science ${ }^{1}$
}

\author{
Mustafa Ŭgraş ${ }^{2}$ \\ Selçuk Aydemir ${ }^{3}$ \\ Erol Asilturk ${ }^{4}$
}

\begin{abstract}
The aim of this study is to determine science teacher candidates' (PSTs) levels of associating their chemistry knowledge with daily life and to examine the relationship between these levels and their attitudes towards teaching science. The study is a descriptive study conducted through the survey method. This study was carried out with 30 PSTs in the part of science teacher education at the College of Education in their final semester. As the data collection tools, an open-ended questionnaire, which was developed by Kiyıc1 and Aydoğdu (2011), was applied to determine the PSTs' levels of associating their chemical knowledge with daily life. Also, the "Science Teaching Attitude Scale" developed by Thompson and Shringley (1986) and adapted into Turkish by Özkan, Tekkaya and Çakıroğlu (2002) was used to determine PSTs' attitudes towards teaching science. The data obtained from the open-ended questionnaire analyzed based on the three categories that were used by Vazquez-Alanso and Manassero-Mas (1999). Findings obtained from the data showed that PSTs' level of associating their chemistry knowledge with daily life was low. Results of the statistical analyses showed that there was a significant relations between level of associating their chemistry knowledge with daily and their attitudes towards teaching science.
\end{abstract}

Keywords: Science; teaching chemistry; chemistry of daily life; attitudes towards teaching science.

\section{Introduction}

The aim of the Science courses is to teach students scientific knowledge along with helping them to understand how to apply this knowledge to their daily lives (Pınarbaşı et all, 1998). People strive to understand and structure the world they live in throughout their lives. Studies on this situation showed that people interpret their world through learning processes that are conducted simply (Tversky \& Kahneman, 1982; Todd \& Gigerenzer, 2000; Leighton\&Sternberg, 2004;

\footnotetext{
${ }^{1}$ A summary of this research was presented in the 5th National Chemistry Education Congress, 7-9 September 2017, Elazı̆̆.

${ }^{2}$ Assistant Professor, Firat University, Faculty of Education, Department of Basic Education, mugras@firat.edu.tr

3 Assistant Professor, Mus Alpaslan University, Faculty of Education, Department of Basic Education, s.aydemir@alparslan.edu.tr

${ }^{4}$ Prof. Dr, Firat University, Faculty of Education, Department of Science and Maths Education, ecil@,firat.edu.tr
} 
Uğraş, M., Aydemir, S., \& Asiltürk, E. (2017). Analysis of pre-service science teachers' level of associating their chemistry knowledge with daily life and the relationship between these levels and their attitudes towards teaching science. Journal of Human Sciences, 14(4), 4539-4545. doi:10.14687/ihs.v14i4.5105

Stains\&Talanque, 2007). Associating science courses into daily life is also not a strong teaching strategy for teachers, but has an outstanding contribution to significant and permanent learning (Mayoh\&Knutton, 1997; Campbell\&Lubben, 2000; McCann, 2001; Dogan, Kivrak\&Baran, 2004). Chemistry subjects are crucial fields of science which are applied in all areas of life. The fact that students cannot fully understand chemistry, even though it has become expanded within our lives, has been stated by Huntemann et all (1999) in that the subjects of chemistry should be interpreted through daily life. Gilbert, Bulteb and Pilot (2011) underlined that a better understanding of chemistry subjects can be achieved by associating more frequently the subjects with daily life.

Science teachers have a crucial role in students' understanding the subjects of chemistry and developing a positive attitude towards the chemistry. Emphasizing the role of the courses in students' daily lives and associating the subjects with daily life during the lessons will contribute to significant and permanent learning. The aim of this study is to determine PSTs' levels of associating their chemistry knowledge with daily life and to examine the relationship between these levels and their attitudes towards teaching science.

\section{Aim of the Study}

The aim of this study is to determine science teacher candidates' level of associating the subjects of chemistry with daily life and to examine the relationship between these levels and their attitudes towards teaching science. The following research questions formed the basis for this study:

1) What is PSTs' levels of associating their chemistry knowledge with daily life?

2) What is PSTs' levels of associating their chemistry knowledge with daily life and the relationship between these levels and their attitudes towards teaching science?

\section{Method}

The screening method was selected to determine the extent to which pre-service science teachers can associate their chemistry knowledge with their daily lives. The screening method, which is among the non-empirical quantitative research methods, was used in this study (Johnson, 2001; Johnson and Onwuegbuzie, 2004). The screening method is a research approach based on describing an event with its past or current state, comparing the relationship between the variables and collecting the data during a specific period of time (Karasar, 2002).

\subsection{Sample}

The study sample consisted of 30 PSTs studying in their final year in the Part of Science Education Program participated in the study.

\subsection{Data Collection Tools:}

A scale consisting of 20 open-ended questions, developed by Kıyıcı and Aydoğdu (2011) to determine PSTs' levels of associating scientific information on physics, chemistry and biology with daily life, was used to determine PSTs' levels of associating the subjects of chemistry with daily life in this study. After the required arrangements by consulting field experts, seven open-ended questions were selected and this questionnaire was completed.

The "Science Teaching Attitude Scale", developed by Thompson and Shringley (1986) and adapted into Turkish by Özkan, Tekkaya, and Çakıroğlu (2002), was used to determine PSTs' attitudes towards teaching science in the study. This scale was consisted of 21 items with five-point Likert-type scale ranging from "strongly agree" to "strongly disagree". 
Uğraş, M., Aydemir, S., \& Asiltürk, E. (2017). Analysis of pre-service science teachers' level of associating their chemistry knowledge with daily life and the relationship between these levels and their attitudes towards teaching science. Journal of Human Sciences, 14(4), 4539-4545. doi:10.14687/ihs.v14i4.5105

\section{Findings}

The qualitative answers that PSTs gave to the open-ended questions analyzed based on the three categories (0, 1, 3.5 point) that were used by Vazquez-Alanso and Manassero-Mas (1999). 3.5 points were given for each scientific view, 1 point for each partial scientific view and 0 point for each non-scientific view.

\begin{tabular}{|c|c|c|}
\hline Scientific view & Partial scientific view & Non-scientific view \\
\hline $\begin{array}{l}\text { Answer is scientifically } \\
\text { sufficiently explained, with no } \\
\text { partial understandings or } \\
\text { misunderstandings. }\end{array}$ & $\begin{array}{l}\text { Answer is scientifically partly } \\
\text { explained, with no } \\
\text { misunderstandings. }\end{array}$ & $\begin{array}{l}\text { Non-scientific, wrong } \\
\text { expressions, misunderstandings. } \\
\text { Or not answered. }\end{array}$ \\
\hline 3.5 points & 1 point & 0 points \\
\hline
\end{tabular}

The ranges of mean score that were considered in evaluating the findings of the science teaching attitudes scale were; "I strongly disagree" for 1.00-1.80, "I disagree" for 1.81-2.60, "I'm not sure" for 2.61-3.40, "I agree" for 3.41-4.20 and "I strongly agree" for 4.21-5.00.

The codes that indicate the opinions of PSTs about associating their scientific chemistry knowledge with daily life are given on Table 1.

Table 1: Score Distributions of PSTs' Statements about Associating Chemistry Subjects to Daily Life

\begin{tabular}{|c|c|c|}
\hline $\begin{array}{l}\text { Scientific view } \\
\text { (3.5 points) }\end{array}$ & $\begin{array}{l}\text { Partial view } \\
\text { (1 point) }\end{array}$ & $\begin{array}{l}\text { Non-scientific view } \\
\text { (0 points })\end{array}$ \\
\hline$\%$ & $\%$ & $\%$ \\
\hline
\end{tabular}

Hydrochloric acid is carried in plastic containers

18

60.00

8

26.67

4

We use plastic instead of glass containers to freeze

water into ice.

Food is cooked faster in pressure cookers.

Soaps have slippery layers.

We place preserve jars in hot water when their lids won't

Aluminum and steel are used in the production of saucepans and frying pans. Icy roads are salted when it snows.

\begin{tabular}{llllll}
20 & 66.67 & 7 & 23.33 & 3 & 10.00 \\
23 & 76.67 & 7 & 23.33 & 0 & 0.00 \\
\hline
\end{tabular}

PSTs were asked to explain carrying hydrochloric acid with plastic containers according to the cause-effect relationship. $18(60.00 \%)$ PSTs scientifically explained this question at a sufficient level. Eight (26.67\%) PSTs gave a partly scientific answer and the remaining four $(13.33 \%)$ PSTs were observed to give a wrong answer to the question. Examples of the answers that PSTs gave are as follows:
"...Hydrochloric acid is actually an acid chemical (HCI), this acid does not react with plastic objects and can be carried in plastic containers..." (PST23) (3.5 points)
"...Hydrochloric acid is sold in plastic containers, so it must be safe..." (PST20) (0 points) 
Uğraş, M., Aydemir, S., \& Asiltürk, E. (2017). Analysis of pre-service science teachers' level of associating their chemistry knowledge with daily life and the relationship between these levels and their attitudes towards teaching science. Journal of Human Sciences, 14(4), 4539-4545. doi:10.14687/ihs.v14i4.5105

In the study, the PSTs were asked, "We use plastic containers instead of glass containers when we want to freeze water into ice, explain this based on the cause-effect relationship". 23 (76.67\%) PSTs scientifically explained this question at a sufficient level. Seven (20.00\%) PSTs gave partly scientific explanations for the question. The remaining one $(3.33 \%)$ PSTs was observed to give a wrong answer. Examples of the answers that PSTs gave are as follows:

"...When water freezes, its density decreases and volume increases. The dilatation coefficient of plastic containers is higher than the dilatation coefficient of glass, so it expands more and doesn't break like ice..." (PST16) (3.5 points)

"...I don't know why glass breaks when water freezes but plastic containers don't break..." (PST15) (1 point)

The PSTs were asked to explain why food is cooked faster in pressure cookers, based on the cause-effect relationship. $22(73.33 \%)$ PSTs scientifically explained this question at a sufficient level. Eight (26.67\%) PSTs gave partly scientific explanations for the question. Examples of the answers that PSTs gave are as follows:

"...Because steam doesn't go out in pressure cookers the pressure inside increases and the boiling point of the liquid in the pressure cooker rises. Thus, foods are cooked faster..." (PST9) (3.5 points)

"...The steam in pressure cookers is kept inside that's why it gets cooked faster..." (PST5) (1 point)

The PSTs were asked to explain why soap has a slippery layer. 20 (66.67\%) PSTs scientifically explained this question at a sufficient level. Six $(20.00 \%)$ PSTs gave partly scientific explanations for the question. The remaining four (13.33\%) PSTs were observed to give a wrong answer. Examples of the answers that PSTs gave are as follows:

"...Soaps are basic substances. Basic substances give a slippery feeling to the hands. That's why soaps bave slippery layers..." (PST8) (3.5 points)

"...Soaps have a soft feature. That's why they give a slippery feeling while on the hands..." (PST1) (0 points)

The PSTs were asked to explain why the lids of preserve jars can be opened after placing in hot water, based on the cause-effect relationship. 22 (73.33\%) PSTs scientifically explained this question at a sufficient level. Eight (26.67\%) PSTs gave partly scientific explanations for the question. Examples of the answers that PSTs gave are as follows:

"...The dilatation coefficients of glass and preserve jars are different. Lids expand more than glass while at the same temperature and that's how the lids are able to be opened..." (PST16) (3.5 points)

"...When put in hot water, the lid slakes and opens..." (PST15) (1 point)

The PSTs were asked to give the reasons why substances such as aluminum and steel are used in the production of saucepans and frying pans. 20 (66.67\%) PSTs scientifically explained this question at a sufficient level. Seven (23.33\%) PSTs gave partly scientific explanations for the question. The remaining three $(10.00 \%)$ PSTs were observed to give a wrong answer. Examples of the answers that PSTs gave are as follows:

"...Aluminum conducts heat regularly and it cools down fast. However, steel does not conduct heat very fast and is more durable against corrosion. I think it is preferred for these reasons..." (PST14) (3.5 points)

“...They must be preferred because they don't cost much..." (PST2) (1 point)

The PSTs were asked to explain the reasons why icy roads are salted when it snows. 23 $(76.67 \%)$ PSTs scientifically explained this question at a sufficient level. Seven $(23.33 \%)$ PSTs gave partly scientific explanations for the question. Examples of the answers that PSTs gave are as follows:

"...The freezing point of salt is lower than the freezing point of ice. The melting point of the ice on road will be reduced when salted and this will enable the ice to melt..." (PST11) (3.5 points) 
Uğraş, M., Aydemir, S., \& Asiltürk, E. (2017). Analysis of pre-service science teachers' level of associating their chemistry knowledge with daily life and the relationship between these levels and their attitudes towards teaching science. Journal of Human Sciences, 14(4), 4539-4545. doi:10.14687/ihs.v14i4.5105

"...Salt is spread because it melts the ice on the road..." (PST5) (1 point)

It is evident from Table 2 that the attitudes of PSTs towards teaching science were 3.47. This value indicates that PSTs have a positive attitude towards teaching science.

Table 2: PSTs' Attitudes towards Teaching Science

\begin{tabular}{|c|c|c|c|}
\hline Attitudes $\quad$ Towards & $\mathrm{N}$ & $\mathrm{X}$ & S.d. \\
\hline Teaching Science & 30 & 3.47 & .45 \\
\hline
\end{tabular}

The Pearson correlation analysis was conducted to determine the relationship between PSTs' level of associating their chemistry knowledge with daily life and their attitudes towards teaching science. According to Table 3, there is a positive significant relationship between PSTs' levels of associating their chemistry knowledge with daily life and PSTs' attitudes towards teaching science $(\mathrm{r}=.711, \mathrm{p}<.001)$.

Table 3: The Relationships Between PSTs' Attitudes Towards Teaching Science and Their Levels of Associating Chemistry Knowledge with Daily Life

Attitudes Towards Teaching Science

Level of associating

with daily life

**. Correlation is significant at the 0.01 level (2-tailed).

\section{Conclusions and Discussion}

Students' motivations towards their courses will increase when they understand what benefits their knowledge will bring to their daily lives (Parchmann et all, 2006). Thus, for students to understand the subjects, it is crucial that teachers teach scientific information by associating them with daily life (Kıyıc1\&Aydoğdu, 2011; Thompson and Shrigley, 1986; Stavridou and Solomonidou, 1998; Ayas et all, 2001; Erdemir\&Bakırc1, 2009). The extent to which learned knowledge is associated to daily life indicates how well the learning experience has taken place (Campbell\&Lubben, 2000, Göçmençelebi İlkörücü\&Özkan, 2009; Martin, 2009).

When the results of previous studies are considered, PSTs were observed to have failed to convey the scientific information about chemistry to daily life at sufficient levels. According to the literature, scientific knowledge is not fully conveyed to daily life (Pınarbaşi et all, 1998)1, Kıyıcı\&Aydoğdu, 2011; Ayas\&Özmen, 1998; Yiğit, Devecioğlu\&Ayvac1, 2002). PSTs' professional achievements depend on the extent to how well they teach the course subjects to their students. Associating the concepts about chemistry with daily life, rather than directly conveying them, will promote permanent learning and enable students to generate opinions about the different events they encounter in life (Göçmençelebi İlkörücü\&Özkan, 2009; Coştu, Ünal\&Ayas, 2007; Özmen, 2003; Sekerci\&Canpolat, 2014). When the scientific knowledge that PSTs have acquired is not sufficiently conveyed to daily life, then they will not fully benefit their students throughout their professional experience.

Pearson correlation analysis was conducted to examine the relationship between PSTs' level of associating their chemistry knowledge with daily life and their attitudes towards teaching science. It was observed that there is a positive significant relationship between conveying scientific knowledge to daily life and the attitudes towards teaching science. This result suggests that the attitude have an effect on the students' success (Duit\&Treagust, 2003; Bilgin\&Aykac ,2016; Tuan, Chin\&Shieh ,2005; Saricam\&Sahin, 2015). 
Uğraş, M., Aydemir, S., \& Asiltürk, E. (2017). Analysis of pre-service science teachers' level of associating their chemistry knowledge with daily life and the relationship between these levels and their attitudes towards teaching science. Journal of Human Sciences, 14(4), 4539-4545. doi:10.14687/ihs.v14i4.5105

\section{References}

Ayas, A. and Özmen, H. (1998). Asit-Baz Kavramlarının Güncel Olaylarla Bütünleştirilme Seviyesi: Bir Örnek Olay Çalısması. III. Ulusal Fen Bilimleri Ë̆itimi Semposyumu Bildiriler Kitabı. Karadeniz Teknik Üniversitesi.

Ayas, A, Karamustafaoğlu O, Sevim, S. and Karamustafaoğlu, S. (2001). Fen bilgisi öğrencilerinin bilgilerini günlük yaşamla ilişkilendirebilme seviyeleri. Yeni Bin Ylln Başında Fen Bilimleri Eğitimi Sempozyumu. Maltepe Üniversitesi, İstanbul.

Bilgin H and Aykac N (2016) Pre-Service Teachers' Teaching-Learning Conceptions and Their Attitudes towards Teaching Profession. Educational Process: International Journal 5 (2): 139-151.

Campbell B and Lubben F (2000) Learning science through contexts: Helping pupils make sense of everyday situations. International Journal of Science Education 22: 239.

Coştu, B., Ünal, S. \& Ayas, A. (2007). The Use of Dally-Life Events In Science Teaching. Kerşehir Education Faculty Journal 8:197.

Doğan, S. Kivrak, E. \& Baran, Ş. (2004). The Levels of Secondary School Students Making Connection Between Daily Life and The Knowledge Gained During Biology Lectures. Journal of Errincan Education Faculty 6:57.

Duit, R. \& Treagust, DF. (2003). Conceptual change: a powerful framework for improving science teaching and learning. International Journal Of Science Education 25:671.

Erdemir, N. \& Bakırc1, H. (2009). The Change And The Development of Attitudes of Science Teacher Candidates Towards Science Branches, Kastamonu Faculty of Education Journal 17:161.

Gilbert, JK., Bulteb, AMW. \& Pilot, A. (2011). Concept development and transfer in context-based science education. International Journal of Science Educatin 33:817.

Göçmençelebi İlkörücü, Ş. \& Özkan, M. (2009). Effect of Elemantary School Sixth Grade Students' Levels of Connecting Biological Knowledge With Everday Life On Their Achievement. Kastamonu Faculty of Education Journal 17:525.

Huntemann H., Paschmann A., Parchmann L. \& Ralle, B. (1999). Chemie im kontext-ein neues konzept für den chemieunterricht? Darstellung einer kntexttorientierten konzeption für den 11.jahrgant. CHEMKON 6:191.

Johnson, RB. (2001). Toward a new classification of nonexperimental quantitative research. Educational Researcher 30:3.

Johnson, RB. \& Onwuegbuzie, AJ. (2004). Mixed methods research: A research paradigm whose time has come. Educational Researcher 33:14.

Karasar, N. (2002). Bilimsel Araştırma Yöntemi. Ankara: Nobel Yayın Dağıtım.

Kiyıc1, FB. \& Aydoğdu, M. (2011). Determination of Pre-Service Science Teachers' Levels Of Relating The Scientific Knowledge to Their Daily Lives. Necatibey Faculty of Education Electronic Journal of Science and Mathematics Education 5:43.

Leighton, JP. \& Sternberg, RJ. (2004). The Nature Of Reasoning, Cambridge University Press, Cambridge, England.

Mayoh, K. \& Knutton, S. (1997). Using out-of-school experience in science lessons: Reality or rhetoric? International Journal of Science Education 19:849.

McCann, WS. (2001). Science education and everyday action. Unpublished doctoral dissertation, Ohio, USA: The Ohio State University.

Özkan, Ö., Tekkaya, C. \& Çakıroğlu, J. (2002). Fen Bilgisi Aday Öğretmenlerin Fen Kavramlarını Anlama Düzeyleri, Fen Ögretimine Yönelik Tutum ve Öz yeterlik İnançları. V. Fen ve Matematik Kongresi, Ankara.

Martin, DJ. (2009). Elementary science methods: A constructivist approach (5th Edition). USA, CA: Cengage Learning.

Özmen, H. (2003). Chemistry Student Teachers' Levels Of Linking Their Knowledge With Daily Life About Acid And Base Concepts. Kastamonu Education Journal 11: 317. 
Uğraş, M., Aydemir, S., \& Asiltürk, E. (2017). Analysis of pre-service science teachers' level of associating their chemistry knowledge with daily life and the relationship between these levels and their attitudes towards teaching science. Journal of Human Sciences, 14(4), 4539-4545. doi:10.14687/ihs.v14i4.5105

Parchmann, I., Gräsel, C., Baer, A., Nentwig, P., Demuth, R. \& Ralle, B. (2006). Chemie im Kontext - A symbiotic implementation of a context-based teaching and learning approach. International Journal of Science Education 28:1041.

Pinarbaşi, T., Doymuş, K., Canpolat,. N. \& Bayrakçeken, S. (1998). Üniversite kimya bölümü öğrencilerinin bilgilerini günlük hayatla ilişkilendirebilme düzeyleri. III. Ulusal Fen Bilimleri ve Matematik Ë̈itimi Kongresi. Karadeniz Teknik Üniversitesi, Trabzon.

Stains, M. \& Talanquer, V. (2007). Classification of chemical substances using particulate representations of matter: an analysis of student thinking. International Journal of Science Education 29:643.

Saricam, H. \& Sahin, SH. (2015). The Relationship between the Environmental Awareness, Environmental Attitude, Curiosity and Exploration in Highly Gifted Students: Structural Equation Modelling. Educational Process: International Journal 4 (1-2): 7-17.

Sekerci, AR. \& Canpolat, N. (2014). Impact ofArgumentation in the Chemistry Laboratory on Conceptual Comprehension of Turkish Students. Educational Process: International Journal 3 (12): 19-34.

Stavridou, H. \& Solomonidou, C. (1998). Conceptual reorganization and the construction of the chemical reaction concept during secondary education. International Journal of Science Education 20:205.

Thompson, CL. \& Shrigley, RL. (1986). What research says: Revising the Science Attitude Scale. School Science and Mathematics. 86:331.

Tuan, HL., Chin, CC. \& Shieh, SH. (2005). The development of a questionnaire to measure students' motivation towards science learning. International Journal of Science Education 27:639.

Todd, PM. \& Gigerenzer, G. (2000). Précis of simple heuristics that make us smart. Behavioral and Brain Sciences. 23:727.

Tversky, A. \& Kahneman, D. (1982). Judgment under uncertainty: Heuristics and biases. In D. Kahneman, P. Slovic, and A. Tversky (Eds.), Judgment under uncertainty: heuristics and biases. New York: Cambridge University Press.

Yiğit, N., Devecioğlu, Y. \& Ayvac1, HŞ. (2002). İlköğretim fen bilgisi öğrencilerinin fen kavramlarını günlük yaşamdaki olgu ve olaylarla ilişkilendirme düzeyleri. $V$. Ulusal Fen Bilimleri ve Matematik Eğitimi Kongresi. Orta Doğu Teknik Üniversitesi.

Vazquez-Alonso, A. \& Manassero-Mas, MA. (1999). Response and scoring models for hte Views on Science -Technology-Society’ Instrument. International Journal of Science Education 21:231. 